\title{
Legal skills and the SQE: Confronting the challenge head on
}

\section{Introduction}

The approval of the Solicitors Qualifying Examination (SQE) ${ }^{1}$ in April 2018 by the Legal Services Board $^{2}$ heralds the demise of the Legal Practice Course (LPC). The new route to qualification announced by the Solicitors Regulation Authority (SRA) also removes the requirement for a qualifying law degree ${ }^{3}$ prior to entering the legal profession as a solicitor, an undergraduate degree is required but the discipline is no longer prescribed. This change in approach creates new challenges for both Universities and students in relation to the acquisition of legal skills and understanding of professional conduct ${ }^{4}$ and the extent to which these elements should be incorporated into the LLB. Whether or not the LLB provided by an institution aims to include preparation for the SQE, a vocational legal education, or whether the institution offers a liberal law degree without SQE preparation will determine the degree to which practical legal skills and professional conduct will be a requisite. A liberal law degree can be seen as 'one which does not focus on education for a particular purpose other than education itself. It is not aimed at preparing students for a particular job or profession and is not concerned with notions such as employability. ${ }^{5}$ For those institutions offering SQE preparation the challenge may be retaining sufficient opportunities for students to engage with socio-legal writing while also covering the essential practical elements required by the SQE. This is a challenge identified by Rigg as "the dual

${ }^{1}$ SQE is a centralised examination comprising two parts, SQE 1 and SQE 2. It is expected that SQE 1 will be undertaken before the obligatory period of work-experience and SQE 2 following the completion of the work-experience.

${ }^{2}$ Legal Services Board 27 March 2018 http://www.legalservicesboard.org.uk/news_publications/LSB_news/PDF/2018/20180327LS B Approves SRA SQE Application.html

${ }^{3}$ Academic Stage Handbook Schedule Two https://www.sra.org.uk/students/academicstage.page The Foundations of Legal Knowledge are:

a. The key elements and general principles of the following areas of legal study:

i. Public Law, including Constitutional Law, Administrative Law and Human Rights;

ii. Law of the European Union;

iii. Criminal Law;

iv. Obligations including Contract, Restitution and Tort;

v. Property Law; and

vi. Equity and the Law of Trusts.

In addition, students are expected to have received training in legal research.

${ }^{4}$ Reference to professional conduct includes the SRA Code of Conduct 2011 version 19 and the wider ethical consideration applicable to the legal profession.

${ }^{5}$ J. Guth and C. Ashford, "The Legal Education and Training Review: regulating socio-legal and liberal legal education?” (2014) The Law Teacher, 48 (1). pp. 5-19. p 6. 
function of providing a liberal legal education while facilitating student and external expectations of employability". ${ }^{6}$

Following the implementation of the SQE students will be assessed in the practical legal skills of research and writing as part of both SQE $1^{7}$ and SQE 2 but will not be assessed in the legal skills of Client Interviewing, Advocacy/Persuasive oral communication, Case and Matter Analysis and Legal Drafting until SQE 2, once the work experience element of qualification has been completed. SQE 1 will also assess students in the elements of professional conduct identified in category $\mathrm{A} 1^{8}$ across SQE 1 assessments in all six Functioning Legal ${ }^{9}$ Knowledge areas ${ }^{10}$. Historically, responsibility for much of the practical legal skills and professional conduct teaching and assessment has fallen to the vocational stage of legal education, sometimes at the expense of innovations in these areas at the academic stage. Rigg notes that 'the two tier nature of legal education in the UK, with an academic stage and a vocational stage, can give rise to a stultifying effect on innovations in undergraduate legal education. ${ }^{11}$ Students who undertake the LPC currently will receive teaching and be assessed in practical legal skills and professional conduct resulting in the acquisition of a level of competence before entering the work experience element of qualification. Once the requirement to successfully complete the LPC is replaced by the need to pass the SQE, the compulsory requirement to undertake this teaching and assessment may be lost if not included in the LLB provision, which 'may lead to greater pressure on legal education providers to incorporate some of the skills from that course into existing undergraduate law programmes. ${ }^{, 12}$ The question then is whether LLB courses should increase the amount

${ }^{6}$ D. Rigg, "Embedding employability in assessment: searching for the balance between academic learning and skills development in law: a case study" (2013) The Law Teacher pp. $404-405$

${ }^{7}$ Solicitors Qualifying Examination: Draft Assessment Specification October 2016 Stage 1 Practical Legal Skills Assessment p 50 - 51.

${ }^{8}$ Solicitors Qualifying Examination: Draft Assessment Specification October 2016 P. 73 A1 Act honestly and with integrity, in accordance with legal and regulatory requirements and the SRA Handbook and Code of Conduct, including:

a) Recognising ethical issues and exercising effective judgment in addressing them.

b) Understanding and applying the ethical concepts which govern their role and behaviour as a lawyer.

c) Identifying the relevant SRA principles and rules of professional conduct and following them.

d) Resisting pressure to condone, ignore or commit unethical behaviour

e) Respecting diversity and acting fairly and inclusively.

${ }^{9}$ Principles of Professional Conduct, Public and Administrative law, and the Legal Systems of England and Wales; Dispute Resolution in Contract or Tort; Property Law and Practice; Commercial and Corporate Law and Practice; Wills and the Administration of Estates and Trusts; Criminal Law and Practice.

${ }^{10}$ Solicitors Qualifying Examination: Draft Assessment Specification October 2016 Annex 2 SQE Assessment Mapping p.77.

${ }^{11}$ Rigg, supra n. 6 pp. 404-420.

${ }^{12}$ N. McNamara, “Authentic assessment in contract law: legal drafting” (2017) The Law Teacher 51:4, 486-498 p.487. 
of practical legal skills and professional conduct in the curriculum and, if so, how this should be delivered and assessed.

The current uncertainty surrounding the SQE and the preparation options that will be available for students should also be borne in mind. It is not yet clear whether graduates will attempt the SQE immediately following completion of an undergraduate degree, without any further legal education, or whether most students will undertake a further year of SQE preparatory post graduate study. If the second option becomes the 'usual' education route then intensive practical legal skills and professional conduct teaching and assessment will presumably be incorporated into that programme. However, as things currently stand the SRA have stated the only requirement before attempting SQE 1 is that an individual be a graduate. If a student enrolls on an LLB which offers SQE preparatory modules, should the LLB then offer the opportunity to acquire the necessary practical legal skills? Following the consideration of the success of a problem solving activity in a law module, Ryan concluded, 'if law schools aim to produce graduates who are ready to practice law, then they need to ensure that the curriculum supports this intended outcome.' 13

This article will briefly consider the development of legal skills in legal education since 1971 and consider possible methods of incorporating practical legal skills and professional conduct teaching on a post SQE LLB programme including the use of authentic assessments, discrete skills teaching in modules, use of legal technology in teaching and student preparation and non-credit bearing incremental portfolio of evidence utilising clinical legal education opportunities.

\section{Historical Development of Practical Legal Skills and Professional Conduct in Legal Education}

Over the last five decades there have been a number of committees, reports and initiatives considering what should be included in a law curriculum and the appropriate balance between practical and academic legal education. Most of these have produced recommendations, but not requirements, for the providers of legal education. The recommended emphasis that should be placed on practical legal skills and professional conduct has varied but the identification of these areas is a common thread throughout. Some reviews have focused largely on the vocational stage of legal education while others have encompassed the wider law curriculum. Kielb notes that, 'one of the primary issues of the debate on the model of legal education is the relationship between theory taught at universities and skills necessary in legal practice. ${ }^{, 14}$

\footnotetext{
${ }^{13}$ P. Ryan, “Teaching collaborative problem-solving skills to law students” (2017) The Law Teacher 51:2, 138-150, p.147.

${ }^{14}$ M. Kielb, "Legal Education from the Perspective of Legal Practice” (2017) Onati Socio-legal Series [online], 7(8), 1636-1646.
} 
The Ormrod Committee on Legal Education (1971) ${ }^{15}$ identified that, as a result of the examinations used at the time, the universities were placing insufficient emphasis on the skills required to be a practitioner ${ }^{16}$. The report recommended that the academic stage of training should be the law degree with the vocational stage being an element of university based training followed by supervised practical experience. The 'foundations for the continuing development of professional skills and techniques ${ }^{, 17}$ would be provided during the vocational stage.

Following the publication of the Ormrod Report, the Society of Public Teachers of Law considered the report. Professor Beinart noted that vocational courses could be incorporated into an academic law degree and so could form part of this stage of training $^{18}$. It was further observed that, 'the most valuable part of the vocational course would in fact be that part dealing with practical legal skills. ${ }^{19}$ However, little advance was made in the increase of skills teaching and assessment in legal education at this time.

The Benson report (1979) ${ }^{20}$ did not make recommendations in relation to the integration of academic and vocational stages of education or specifically comment on practical legal skills and professional conduct, but it did recommend a Joint Committee on Legal Education which would have the same terms of reference as the Advisory Council and would report to the professional bodies on 'all matters affecting the education and training of candidates for entry to the legal profession. ${ }^{21}$

The Marre Report (1988) contained a recommendation that teaching practical legal skills should be included in the vocational stage of teaching and assessment. ${ }^{22}$ This was followed in May 1990 by an announcement by the Law Society that the vocational course, the Law Society Finals, would place a greater emphasis on practical legal skills and then by the introduction of the LPC in 1993. The LPC required the legal skills of practical legal research; drafting; legal writing, advocacy and interviewing, together with professional conduct, ${ }^{23}$ to be taught and assessed as competent before successful completion of the academic stage of vocational training.

${ }^{15}$ Report of the Committee on Legal Education, CMND. No. 4595 (1971) Ormrod, Roger; Great Britain. Committee on Legal Education; Great Britain. Lord Chancellor's Department Book. English.

Published London: H.M.S.O., 1971.

${ }^{16}$ Ormrod supra n. $1383-86,100$.

${ }^{17}$ Ormrod supra n. 13125.

18 'The Ormrod Report.' (1972) 12(1) J Soc'y Pub Tchrs L ns 39 page 16.

19 'The Ormrod Report' supra n. 16, 16.

${ }^{20}$ Royal Commission on Legal Services (1979). Final Report. [The Benson Report] Cmnd 7648, London, HMSO.

${ }^{21}$ Benson supra n. 18, p. 331.

${ }^{22}$ The Committee on the Future of the Legal Profession (London, 1988), A Time for Change (General Council of the Bar and the Law Society).

${ }^{23}$ Supra n. 4. 
The Lord Chancellor's Advisory Committee on Legal Education and Conduct (ACLEC) published its first report in $1996^{24}$ which identified that a law degree should stand alone rather than be tied to a specific vocation ${ }^{25}$. However, the report contained recommendations only and went on to describe what both the academic and vocational stages should aim for ${ }^{26}$, including professional skills, without making a distinction between the two stages.

In 2001 the Law Society announced a Training Framework Review (TFR) which proceeded through a succession of consultations resulting in the production of day one outcomes for qualification as a solicitor receiving the approval of the Law Society Council in 2005. These outcomes were further refined in 2007 and included, in Group $\mathrm{D}$, legal, professional and client relationship knowledge and skills and in Group F, professional values, behaviours, attitudes and ethics. Group D included evidence of the ability to undertake legal research, communicate effectively, both orally and in writing and advocate a case on behalf of a client. Group F required an understanding and 'knowledge of the values and principles upon which the rules of professional conduct have been developed. ${ }^{27}$ The TFR did not allocate specific outcomes to any particular stage prior to qualification meaning that they could pervade both the academic and vocational stages of training. In most cases it has been the vocational stage that has delivered teaching and assessment in the areas of professional conduct and practical legal skills.

A study ${ }^{28}$ of recently qualified solicitors conducted between 2001 and 2002 found 'that law degrees provided them with basic legal skills and awareness but that both their studies and their competence in practice would have benefitted from more experience of applying the law in practical situations'. ${ }^{29}$ These views are supported by the findings in the Carnegie Report ${ }^{30}$ which identified that legal education faces a challenge in balancing the interests of legal educators with the needs of the legal profession and the requirement to have the skill to act in the best interests of the public. Although this report considered the provision of legal education in America it is a challenge that is equally faced by providers of legal education in other jurisdictions. The Report ${ }^{31}$ identified that 'students should be provided with 'substantial experience with practice'

${ }^{24}$ Lord Chancellor's Advisory Committee on Legal Education and Conduct (1996). First Report on Legal Education and Training. [ACLEC Report] London.

${ }^{25}$ Ibid Recommendation 4.1.

${ }^{26}$ ACLEC supra n. 23 para 2.8 'intellectual integrity and independence of mind, core knowledge, contextual knowledge, legal values, and professional skills'.

${ }^{27}$ Solicitors Regulation Authority Education and Training Committee Day one outcomes April 2007

${ }^{28}$ A. Boon \& A. Whyte "Looking back: Analysing experiences of legal education and training" The Law Teacher (2007) 41:2, 169 - 190.

${ }^{29}$ Boon supra n. 26 p. 174.

30 The Carnegie Foundation for the Advancement of Teaching "Educating Lawyers Preparation for the Profession of Law” (2007) http://archive.carnegiefoundation.org/pdfs/elibrary/elibrary_pdf_632.pdf

${ }^{31}$ Carnegie supra n. 29, p. 9. 
and be exposed to professional ethics. It went on to identify that professional legal education should be 'fully integrated into the curriculum'.

The 'new' version of the LPC, which remains the current version, was introduced in March 2008 and introduced the LPC Written Standards. These requirements for the vocational stage of legal education can now be found in the SRA Training Regulations $2014^{33}$ and the SRA Legal Practice Course Outcomes 2011. ${ }^{34}$ The 2011 Outcomes require a student to demonstrate an understanding of and ability to apply the Principles and the Code of Conduct to practical legal situations ${ }^{35}$ and the ability to demonstrate basic competency in the area of legal skills including practical legal research, drafting, legal writing, interviewing and advising and advocacy. ${ }^{36}$

Conclusions reached by the Legal Education and Training Review (LETR) in $2013^{37}$ include that there were 'areas of required skills which do not change and must continue to be taught, ${ }^{38}$ and that there was a need to 'strengthen requirements for education and training in legal ethics. ${ }^{39}$ Dagilyte and $\mathrm{Coe}^{40}$ identified areas of legal training that needed to be addressed following the LETR which included the skills and ethics needed by lawyers. The overriding conclusion of the LETR was that, although it was necessary to continue to provide legal education in practical legal skills and professional conduct, this should be done in a more robust way. Recommendations 6 identifies the need for a consistent approach to the achievement of "appropriate learning outcomes in respect of professional ethics, legal research, and the demonstration of a range of written and oral communication skills," while recommendation 7 identifies a broader recommendation that "an understanding of the relationship between morality and law" is acquired. These recommendations go beyond the prescribed coverage of the Solicitors Code of Conduct $^{41}$ currently provided by the LPC and the suggestion of the LETR was that coverage of ethics may be suited to a "broad approach" 42 , rather than being restricted to conduct rules or principles. The focus of the report was on the provision of education and training at the vocational stage, currently the vocational stage of legal education is largely provided by the LPC. However, Guth and Ashford noted that "if regulators take

${ }^{32}$ Carnegie supra n. 29, p. 9.

${ }^{33}$ SRA Training Regulations 2014 - Qualification and Provider Regulations. Version 19 of the Handbook was published on 1 October 2017.

${ }^{34}$ SRA Legal Practice Course Outcomes 2011 published September 2011.

${ }^{35}$ SRA Outcomes supra p. $6-7$.

${ }^{36}$ SRA Outcomes supra p. $19-24$.

${ }^{37}$ J. Webb, J. Ching, P. Maharg and A. Sherr, "Setting Standards: The Future of Legal Services Education and Training Regulations in England and Wales" (London, Legal Education and Training Review, 2013) (LETR Report).

${ }^{38}$ Webb supra n. 37 p. 7.

${ }^{39}$ Webb supra n. 37 p. 10.

${ }^{40}$ E. Dagilyte and P. Coe "Professionalism in higher education: important not only for lawyers" (2014) The Law Teacher 48:1, 33-50 p. 40

${ }^{41}$ Supra n. 4

${ }^{42}$ Supra n. 37 note 7.89 p. 307 
up the recommendations made, the impact on UG law degrees could be significant.”"43 Following a review of the LETR and a consideration of the definition of 'professionalism' ${ }^{44}$, Dagilyte and Coe concluded that, "it can be argued that the development and inculcation of professional skills, attitudes and values should feature in many undergraduate degrees." 45 The report identified the need to improve writing skills, including an improved understanding of the skills needed when writing for different purposes, and recommended the introduction of discrete assessments in a number of areas including legal research and writing ${ }^{46}$. Guth and Ashford, whilst acknowledging that greater focus on writing and research skills "sounds promising" ${ }^{47}$ identify the possible negative implications if the outcome is "a focus on writing for legal professional purposes rather than on writing generally," suggesting that a solution would be for students to learn "how to express themselves clearly and accurately and be exposed to a variety of writing tasks." ${ }^{48}$ Recommendation $12^{49}$ identified the need for the adequacy of advocacy training to be addressed although this recommendation is specifically in reference to the provision of advocacy teaching and assessment on the LPC. The LETR recommends that advocacy teaching and assessment be removed from the LPC and dealt with either as a "separate 'endorsements' on the practising certificate" ${ }^{50}$ following specialised training either during or after the training contract; or form part of the training contract as required professional development. ${ }^{51}$ The requirement to be competent in advocacy remains for successful completion of the LPC but these recommendations will be relevant with the introduction of the SQE as advocacy will then be assessed following the required period of work experience as part of SQE 2. The teaching and assessment of these areas of legal skills and professional conduct on the LPC has evolved to be increasingly rigorous and to offer further support for students. With the LPC being replaced, in time, by the SQE, consideration needs to be given to the extent to which, if at all, LLB courses should take over the provision of teaching of practical legal skills and professional conduct and the assessment of competency in those areas.

The QAA Subject Benchmark for Law ${ }^{52}$ identifies skills as being a key component of a well skilled graduate with considerable transferable generic and subject-specific knowledge, skills and attributes. ${ }^{53}$ It confirms that a law graduate should acquire legal

${ }^{43}$ Guth supra n. 5 p. 6.

${ }^{44}$ Dagilyte supra n. 40 p. 35

${ }^{45}$ Dagilyte supra n. 40 p. 44

${ }^{46}$ Supra n. 37 recommendation 11

${ }^{47}$ Guth supra n. 5 p. 16

${ }^{48}$ Guth supra n. 5 p. 16

${ }^{49}$ Supra n. 37 recommendation 12 p.309

${ }^{50}$ Supra n. 37 note 7.95 p.309

${ }^{51}$ Supra n. 37 note 7.96 p.309

${ }^{52}$ QAA Subject Benchmark Statement: Law July 2015: UK Quality Code for Higher Education Part A: Setting and maintaining academic standards: http://www.qaa.ac.uk/en/Publications/Documents/SBS-Law-15.pdf (accessed $9^{\text {th }}$ July 2018).

${ }^{53}$ QAA supra p. 6. 
knowledge, general intellectual skills and legal skills but that the balance of these in the curriculum is to be determined by the individual law school. ${ }^{54}$ The statement supports the scaffolding approach in relation to the development of both subject knowledge and skills and the integration of skills teaching into the academic teaching ${ }^{55}$.

\section{Current position}

The impending changes to the route to qualification have resulted in some Law Schools considering the curriculum content of the LLB and if and how it should be adapted to meet the challenges presented by the SQE. Turner et al note that, 'the law curriculum needs to combine the learning of substantive law with the experience of practice to enhance employability, professionalism and communication skills. ${ }^{56}$ There are those who advocate the need to retain a liberal degree, including Bradney who believes that narrow vocational courses are not part of a liberal legal education, ${ }^{57}$ and those who consider that a theoretical liberal law degree is no longer appropriate in the current climate of employability. Molot ${ }^{58}$ urges law schools to not only incorporate practical and clinical opportunities in the curriculum but also suggests that, 'during the second and/or third year of law school, students should take at least one course on the economics of law practice and the market for legal services.' Dagilyte and Coe argue that 'higher education needs to be combined with skills and values training to prepare graduates that are fit both for non-legal employment, as well as for professional legal training. ${ }^{59}$

The planned introduction of the SQE means that, potentially from 2020, students will be assessed in the skills of legal writing and practical legal research and in professional conduct in stage 1 of the SQE ${ }^{60}$. The proposed skills assessment will last for three hours and will consist of two tasks. The first is a structured research task which will be carried out online and will require the student to identify reliable sources, produce a research trail and apply the findings to a legal issue. The second is a two part writing task in which students will be required to produce two letters, one to a client and one to a third party, using house style. The students will be required to utilise language appropriate to the recipient, provide accurate identification of the issues and show proficiency in the use of grammar. How the letter is written is likely to have equal importance as what is written. Comments received from students following a study conducted by Boothby and

\footnotetext{
${ }^{54}$ QAA supra p. 8.

${ }^{55}$ QAA supra p. 10.

${ }^{56}$ J. Turner, A. Bone \& J. Ashton, "Reasons why law students should have access to learning law through a skills-based approach” (2018) The Law Teacher 52:1, 1-16 p.3.

${ }^{57}$ A. Bradney, Conversation, Choices and Chances: The Liberal Law School in the Twenty-First Century (Oxford, Hart Publishing, 2003 p85-104).

${ }^{58}$ J. T. Molot, "Purism and Pragmatism in the Legal Profession” (2018) 31 Geo. J. Legal Ethics $1 \mathrm{p} 24$

${ }^{59}$ E. Dagilyte and P. Coe "Professionalism in higher education: important not only for lawyers" (2014) The Law Teacher 48:1, 33-50 p. 42.

60 Solicitors Qualifying Examination: Draft Assessment Specification October 2016 p.50.
} 
Sylvester ${ }^{61}$ 'highlight a significant difference between the process of writing in the academic setting and practical legal writing.'

The SRA issued the new competency statement for solicitors ${ }^{62}$ in 2015 which identifies the standards required in order for a solicitor to display the necessary continuing competencies. These include more detailed requirements relating to writing including ${ }^{63}$ having the ability to know when to avoid technical language, ensuring the language used is appropriate to the recipient, showing sensitivity when needed and using the correct formalities. These competencies are currently taught and assessed on the LPC but, due to writing being assessed at SQE 1, students will need to have developed this skill by the end of the academic stage of legal education.

\section{Potential approaches to integration}

Authentic teaching activities aim to provide students with the opportunity to deal with realistic legal situations and to apply the academic law knowledge they have acquired. 'Designing law units that enable students to use their new knowledge and skills to solve authentic legal problems makes a substantial contribution to their preparation for legal practice. ${ }^{64}$ Authentic teaching activities would include class room activities designed to replicate the 'real world' by using realistic scenarios, authentic documentation, practice based technology and the creation and development of case files utilising a house style to replicate practice.

There are various methods that can be used to incorporate authentic teaching activities into LLB modules to increase the coverage of practical legal skills and professional conduct, including the use of discrete teaching and assessment of individual skills and professional conduct areas in a way that replicates the current approach on the LPC at some institutions. This allows the freedom to develop students understanding of the

${ }^{61}$ C. Boothby \& C. Sylvester "Getting the fish to see the water: an investigation into students' perceptions of learning writing skills in academic modules and in a final year real client legal clinic module” (2017) The Law Teacher 51:2, 123-137, p. 131.

${ }^{62}$ Solicitors Regulation Authority, "Training for Tomorrow: A Competence Statement for Solicitors” (11 March 2015”.

${ }^{63}$ SRA Statement of solicitor competence C1 Communicate clearly and effectively, orally and in writing, including

a. Ensuring that communication achieves its intended objective

b. Responding to and addressing individual characteristics effectively and sensitively

c. Using the most appropriate method and style of communication for the situation and the recipient(s)

d. Using clear, succinct and accurate language avoiding unnecessary technical terms

e. Using formalities appropriate to the context and purpose of the communication

f. Maintaining the confidentiality and security of communications

g. Imparting any difficult or unwelcome news clearly and sensitively

Available from http://www.sra.org.uk/competence/

${ }^{64}$ P. Ryan, “Teaching collaborative problem-solving skills to law students” (2017) The Law Teacher 51:2, 138-150 p. 147. 
subject, reflect on the attributes of the skill and become more familiar with the practical implications of the areas of professional conduct. Identifying the practical legal skill or professional conduct area in this way avoids the possibility that it will be overlooked due to the focus placed on the academic content of the module.

The use of clinical legal education has become more widespread in recent years. Law schools in Australia have adopted clinical programmes following pressure from students and the profession who were demanding an increase in graduate employability and also from the judiciary who considered there was a need to improve the level of professionalism and the ethical standards of law graduates. ${ }^{65}$ An internet search of LLB modules offered across numerous institutions in England identifies the availability of practical skills based and clinical legal modules ${ }^{66}$, suggesting that the inclusion of practical skills based legal education is already prevalent in Law Schools. Davies and Woo note that, "the link to employability in law schools has become increasingly explicit with employability rankings frequently prominently advertised. The message being that law schools will ensure that their students have the skills and attributes employers require." ${ }^{67}$ The 2014 Law Works ${ }^{68}$ report found that $70 \%$ of all law schools offer pro bono opportunities for students. The report concluded that, 'the balance between educational and legal service delivery objectives is being achieved with a discernible (and planned) increase in the number and scope of clinics and the presence of a clinic as a discrete aspect of the taught (and assessed) curriculum.' For institutions that already offer a variety of clinical legal opportunities, including pro bono clinics, there are a number of learning and assessment opportunities. In order for a student to provide advice to a member of the public they will need to conduct research which will be checked by a supervising lecturer or practitioner. The student will then prepare a letter of advice which will also need to be checked. Both of these stages are capable of being formally assessed and both offer opportunities for feedback to be given. However, in order for all students that intend to engage with the SQE preparatory modules to be provided with the opportunity to participate, any scheme will need to be able to cater for large student numbers. Another possibility for student learning using clinical opportunities is a reflective portfolio which will require the student to participate in a minimum amount of activities for a minimum amount of hours. Submission of work covering various practical legal skills and identifying professional conduct areas will allow feedback from supervising staff and reflection on the part of the student. Students will have the opportunity to develop practical legal writing skills and research skills including the preparation of a research trail, both of which will be assessed in SQE 1 . In

\footnotetext{
${ }^{65}$ Adrian Evans (2013) Best Practices: Australian Clinical Legal Education, The Law Teacher, 47:3, p.422

${ }^{66}$ Examples include Legal Skills and Methods module at the University of Birmingham; Legal Skills module at University of York; Applied Legal Skills and Research module at the University of Wolverhampton and Approaches to Law and Lawyering Skills module at Northumbria University

${ }^{67}$ Gemma Davies; Margaret Woo, Navigating Troubled Seas: The Future of the Law School in the United Kingdom and the United States, 5 J. Int'l \& Comp. L. 43 (2018) p.63

${ }^{68}$ The LawWorks Law School Pro Bono and Clinic Report 2014. Damian Carney, Frank Dignan, Richard Grimes, Grace Kelly and Rebecca Parker.
} 
addition students will have the opportunity to develop communication and drafting skills, both of which are valued by employers. Clinical legal education is increasingly using a reflective journal with positive results as, 'it compels students to tackle their clinical experience in a critical and more profound manner'. ${ }^{69}$ Again though, this is likely to be a problematic option for institutions if it is to be a compulsory module, or one which a large number of students want to take, as there may be a limit in the number of students who can be accommodated at a pro bono law clinic. If the portfolio was to be non-credit bearing then there may be difficulties encouraging students to participate initially and to remain engaged for the duration of the LLB. The portfolio could alternatively be designed to be offered in a shorter version and be credit bearing within a clinical legal module as was done by the Faculty of Law at Hong Kong University $^{70}$.

Using technology in the provision of clinical legal education is an option which can go some way to removing the limit on the number of students that can be involved. One such method piloted by Queensland University of Technology was a 'virtual law placement in which students use technology to complete a real world project in a virtual workplace under the guidance of a workplace supervisor, ${ }^{71}$ The advantage of this scheme was that it could be made accessible to more students as it did not involve face to face teaching, students were given the opportunity to conduct legal research, develop both written and oral communication skills, gain an understanding of professional conduct and improve legal knowledge. ${ }^{72}$ The students who undertook the virtual law placement were successfully assessed ${ }^{73}$ showing that this method could be adopted as a core module, at least for those students wanting to undertake an SQE focused LLB.

Chow ${ }^{74}$ identifies an e-technology programme which provides simulation activities aimed at improving practical knowledge and professional skills. Simulated Professional Learning Environment (SIMPLE), explained by The Higher Education Academy as:

The SIMulated Professional Learning Environment (SIMPLE) is an open source application consisting of a set of tools with which simulation designers can

${ }^{69}$ R. L. Hyams, “On Teaching Students to Act Like a Lawyer: What Sort of Lawyer?” (2008) International Journal of Clinical Legal Education (2008), p. 21 - 33.

${ }^{70}$ W. W. S. Chow, and F. Tiba, “Too Many 'What's, Too Few 'How's” (2013) European Journal of Law and Technology Vol. 4, No. 1, 2013 p.7.

${ }^{71}$ J. McNamara, T. L. Cockburn and M. J. Shirley, "Creating and enabling opportunities for increased student participation in experience based learning in professional practice" (2009) Experience Based Learning Association Inaugural Conference, 7-9 December 2009, University of Technology Sydney, Sydney.

${ }^{72}$ A. Stickley, "Providing a Law Degree for the 'Real World': Perspective of an Australian Law School” (2011) The Law Teacher 45 (1) 63, p.17.

${ }^{73}$ The assessment comprised an application for a placement (10\% - individual mark), online discussion forum (15\% - individual mark), project outline (15\% - team mark), completed team project and individual report (40\%- 10\% team mark and 30\% individual mark) and ePortfolio entries reflecting on their skill development (20\%).

${ }^{74}$ Chow supra p.9. 
devise and set up simulations, placing students in an appropriate professional context. Developed by the UK Centre for Legal Education, SIMPLE has the potential to deepen student learning in a range of academic disciplines and professional contexts. ${ }^{75}$

SIMPLE was pioneered by five UK Law Schools ${ }^{76}$ and has been adopted by the Australian National University.

Perhaps the most straightforward way of introducing the authentic teaching and assessment of practical legal skills and professional conduct into the LLB is by way of authentic activities and authentic assessments. The methods of teaching and assessment currently used on the LPC are authentic as they incorporate practical scenarios, use authentic documentation and require the students to provide legal advice on real world transactions and problems. In addition students are introduced to practical legal skills which are developed during the course. This type of authentic practical legal education can be embedded into the LLB curriculum but, with the benefit of a longer period of academic study, can be done in an incremental way that allows for the degree programme to be scaffolded using skills and conduct. ${ }^{77}$

A number of academic modules would be suitable for the integration of authentic activities, drafting in contract or property law modules; oral skills in litigation based modules; letter writing in business or probate modules, for example. Legal research could form part of an assessment task or be a preparation requirement for seminars. There are many opportunities to introduce skills into teaching and assessment and this can be done in a 'light touch' way so as not to distract from the academic content. Boothby and Sylvester identified that, 'the journey from year one undergraduate study to legal professional will require students to constantly adapt and transfer their skills. ${ }^{78}$ They conducted a study to explore the development of students writing skills from undergraduate through to vocational education including involvement with clinical legal education opportunities. This was achieved through the use of a 'problem-based practice orientated module ${ }^{79}$ in year two and a practice orientated module in year three which required students to develop a case file. The approach taken in year three is one which is replicated generally on LPC courses where the focus is on simulating practice as much as possible. The study identified that students did not always relate their experience of academic legal writing with the skills needed for practical legal writing leading to a conclusion that a clearer framework was needed.

\footnotetext{
${ }^{75}$ Enhancing learning through technology A guide to resources provided by the Academy and JIS Collaboration Network October 2009. https://www.heacademy.ac.uk/system/files/EnhancingLearningThroughTechnology.pdf

${ }^{76}$ Glasgow Graduate School of Law, the University of Glamorgan, University of Warwick, University of Stirling and the University of the West of England.

${ }^{77}$ For an example of this approach see A. Stickley, "Providing a Law Degree for the 'Real World': Perspective of an Australian Law School” (2011) 45 (1) Law Teacher 63.

${ }^{78}$ Boothby supra p. 124.

${ }^{79}$ Boothby supra p. 125.
} 
Meuller ${ }^{80}$ defines authentic assessment as 'a form of assessment in which students are asked to perform real-world tasks that demonstrate meaningful application of essential knowledge and skills,' and explains that 'authentic learning and assessment emphasizes students' need to learn and subsequently demonstrate the ability to apply the knowledge and skills in real-world or authentic contexts.' According to Berger and Wild ${ }^{81}$, authentic assessment 'tests a student's ability to solve hypothetical problems, which then assess how effectively a student solves a real world problem, and requires students to apply a broad range of knowledge and skills'. When considering appropriate ways of assessing the understanding, knowledge and application of law by students, authentic assessment does have a place as these activities have 'real-world relevance and utility. ${ }^{, 82}$ A law graduate intending to attempt the SQE will need to be able to demonstrate an understanding and application of the law that goes beyond the ability to acquire and understand knowledge of black letter law. Using a form of authentic assessment allows the module team to assess not only the students' retained knowledge but also, by requiring an application of that knowledge to realistic scenarios, their understanding.

Oral assessments are a form of authentic assessment that provides an opportunity to maintain academic rigour and so support a liberal education and develop key employability skills in the process. ${ }^{83}$ Wallace ${ }^{84}$ (2010) argues that 'oral assessment, carefully designed, works at least as well as, and in many cases better than, written assessment at driving deep and effective learning'. In order to successfully tackle an oral assessment the student must have a grasp of the facts and the legal implications and be able to ask relevant questions or argue a legal point. This requires a greater degree of understanding than a written assessment where the student's ability to memorise information may be sufficient for a mere passing grade. This type of oral assessment also allows the lecturer to question the student to determine the extent of understanding and thus allows the better prepared student to demonstrate that understanding through dialogue. Wallace further suggests that, 'oral assessment is also well suited to assessing understanding and analysis, critical thinking and the ability to construct and defend an argument'. Communication skills are transferrable to any area of employment and employers value good communication skills highly. ${ }^{85}$

In order to ensure a progressive and developing understanding of the practical legal skills and professional conduct topics these could be tracked throughout the LLB. This

${ }^{80}$ Mueller, J. "The Authentic Assessment Toolbox: Enhancing Student Learning Through Online Faculty Development,” (2005) Journal of Online Learning and Teaching p.2

${ }^{81}$ D. Berger \& C. Wild, “ Using Authentic Assessment Techniques in Extra \& Co-Curricular Activities (ECCAs) to Improve Teaching Standards on Academic Law Programmes” (2015) Journal of Commonwealth Law and Legal Education, vol 10 , no. 1 , pp. 70-83.

${ }^{82}$ J. Herrington, R. Oliver \& T.C. Reeves, “Authentic tasks online: A synergy among learner, task and technology” Distance Education 27(2), 2006, 233-248. P 236 - 237.

${ }^{83}$ Meuller, supra p.410.

${ }^{84}$ C. J. Wallace, "Using oral assessment in law; opportunities and challenges” (2010) The Law Teacher 44:3, $365-377$

${ }^{85}$ Rigg, supra n. 2 at p. 405. 
could be done using a skills and conduct matrix so that it is clear to the students that practical legal skills and professional conduct pervade the LLB. Stickley ${ }^{86}$ identified Kift's explanation of this type of mapping which is, 'a whole programme matrix onto which the discipline's desirable knowledge, skills and attitudes are carefully plotted for multiple learning opportunities and contexts, increasing in complexity over the course of the degree programme. ${ }^{87}$ Research has shown that students appreciate this scaffolding approach to curriculum design and the learning process. In an study conducted at the University of Wolverhampton in $2015^{88}$ students identified the benefits of being able to identify the acquisition of skills and knowledge over the duration of the course noting, 'I can now see that the stuff I've done in year one is related to the stuff I did in year two each time linking and building it up and is now relating to what I have done in year three.' 'Learning is not a linear process ... taken together, curriculum, teaching, learning and assessment interact in an iterative and sometimes cyclical process ${ }^{89}$. This approach was taken by Queensland University of Technology following a curriculum review, the new curriculum took a 'whole degree approach' which ensured that 'capabilities were appropriately embedded and scaffolded throughout the degree.' Utilising the teaching and assessment of practical legal skills and professional conduct in this way would result in a consistent approach being taken to the production of module materials and contribute to a cohesive LLB programme.

\section{Conclusion}

It must be recognised that many LLB students decide not to enter the legal profession which presents a challenge for law schools when designing a curriculum. Rigg notes that 'the age of the employability agenda has necessitated a rethinking of how teaching, learning and assessment activities are organised to satisfy the dual function of providing a liberal legal education while facilitating student and external expectations of employability. ${ }^{91}$ There should be a place for practical legal skills and professional conduct in all LLB programmes but the extent to which they are incorporated should perhaps be determined by whether the LLB is a vocational legal or a liberal legal programme or whether it aims to provide students with flexibility by offering a range of

${ }^{86}$ A. Stickley "Providing a law degree for the "real world": perspective of an Australian law school” (2011) The Law Teacher 45:1, 63-86, p. 11.

${ }^{87}$ Stickley supra p11 referring to S Kift, "Integrating the Knowing, the Doing and the Practise: An Early Australian Case Study of Curriculum Renewal” International Conference on the Future of Legal Education (Georgia State University College of Law, Atlanta: 2008.

${ }^{88}$ Arjunan, A., Bannister, D., Brown, Z., Ellison, L., Jones, D. and Wang, W. “An Investigation into 'Good Practice', Students' and Lecturers' Perspectives on the NSS questions 1-4.” (2016) (Vice Chancellor's Strategic Excellence Initiative projects) unpublished.

${ }^{89}$ L. M. Earl, Assessment as Learning: using classroom assessment to maximize student learning (London, Sage publishing 2003), p.83.

${ }^{90}$ A. Stickley, "Providing a law degree for the "real world": perspective of an Australian law school” (2011) The Law Teacher 45:1, 63-86, p. 1.

${ }^{91}$ D. Rigg, "Embedding Employability in Assessment: Searching for the Balance between Academic Learning and Skills Development in Law: A Case Study” (2013) 47(3) The Law Teacher 404, pp 404-405. 
optional modules allowing the student to customise their programme. It should be possible for those choosing a liberal legal education to still acquire practice relevant skills and knowledge 'because they facilitate or come with the wider learning that constitutes a liberal education ${ }^{92}$, however acquiring practical legal skills and professional conduct understanding as a by-product of acquiring academic knowledge may not be sufficient to prepare a student to attempt SQE 1 .

There is a clear need for students, who intend to attempt the SQE directly following completion of the LLB, to have undertaken teaching in the areas of practical legal research, legal writing and professional conduct. A conclusion reached by Chow, in explanation of the motivation behind the various calls for legal education reform over the last five decades, 'that students are not sufficiently prepared to enter the legal profession' ${ }^{93}$ may, arguably, be relevant again following the implementation of the SQE. Stickley identifies that Queensland University of Technology have designed a practical law degree 'by embedding capabilities throughout the degree and vertically aligning those capabilities in such a way that students can build upon their knowledge and practice the necessary skills. ${ }^{94}$ This may be a more appropriate approach for a law school that is aiming to prepare LLB students to undertake the SQE, with or without the need for further preparation at post graduate level.

Over the last five decades legal education has evolved, today individuals entering the legal profession as a trainee solicitor will have acquired competency in both legal skills and professional conduct and will have the ability to apply the law in a practical way to solve client problems and provide legal advice. It remains to be seen what the new 'standard' route to qualification will be and whether new LLM courses will be widely developed to prepare students for the SQE. However, where the LLB programme offered by an institution includes an element of preparation for SQE 1 and aims to enhance employability of the student in terms of readiness for legal practice, it must make provision for the incorporation of practical legal skills and professional conduct.

\section{Bibliography}

Arjunan, A., Bannister, D., Brown, Z., Ellison, L., Jones, D., Wang, W. (2016) ‘An Investigation into 'Good Practice', Students' and Lecturers' Perspectives on the NSS questions 1-4.’ (Vice Chancellor’s Strategic Excellence Initiative projects) unpublished

Berger, D. \& Wild , C., ' Using Authentic Assessment Techniques in Extra \& CoCurricular Activities (ECCAs) to Improve Teaching Standards on Academic Law Programmes' (2015) Journal of Commonwealth Law and Legal Education, vol 10 , no.

\footnotetext{
${ }^{92}$ Gunn, supra p. 7

${ }^{93}$ Chow, supra p.5

${ }^{94}$ Stickley, supra p. 18
} 
1 , pp. $70-83$

Boon, A. \& Whyte, A. 'Looking back: Analysing experiences of legal education and training,' (2007) The Law Teacher, 41:2, 169 - 190

Boothby, C. \& Sylvester, C. 'Getting the fish to see the water: an investigation into students' perceptions of learning writing skills in academic modules and in a final year real client legal clinic module', (2017) The Law Teacher, 51:2, 123-137

Bradney, A. Conversation, Choices and Chances: The Liberal Law School in the Twenty-First Century (Oxford, Hart Publishing, 2003)

Chow, W. W. S. , Tiba, F., 'Too Many 'What's, Too Few 'How's', European Journal of Law and Technology, Vol. 4, No. 1, 2013

Committee on the Future of the Legal Profession (Great Britain), General Council of the Bar (England and Wales), Law Society (Great Britain) "A time for change: report" General Council of the Bar, 1988

Dagilyte, E. and Coe, P. 'Professionalism in higher education: important not only for lawyers.’ (2014) The Law Teacher, 48:1, 33-50 p 42

Davies, G. and Woo, M. 'Navigating Troubled Seas: The Future of the Law School in the United Kingdom and the United States’, (2018)5 J. Int'l \& Comp. L. 43

Earl, L.M. (2003) Assessment as Learning: using classroom assessment to maximize student learning. (London, Sage), p.83

Enhancing learning through technology A guide to resources provided by the Academy and JIS Collaboration Network October 2009 https://www.heacademy.ac.uk/system/files/EnhancingLearningThroughTechnology.pdf

Evans, A. 'Best Practices: Australian Clinical Legal Education,' (2013) The Law Teacher, 47:3, 421-423

Guth, J. and Ashford, C. "The Legal Education and Training Review: regulating sociolegal and liberal legal education?” (2014) The Law Teacher, 48 (1). pp. 5-19

Herrington, J. Oliver, R. and Reeves, T.C. 'Authentic tasks online: A synergy among learner, task and technology.’ Distance Education, 27(2), (2006) 233-248. P 236 - 237 
Hyams, R. L. 'On Teaching Students to Act Like a Lawyer: What Sort of Lawyer?' (2008) International Journal of Clinical Legal Education. 13, December 2008, p. 21 - 33 13

Kielb, M. 'Legal Education from the Perspective of Legal Practice.' (2017) Onati Socio-legal Series [online], 7(8), 1636-1646.

Kift, S. 'Integrating the Knowing, the Doing and the Practise: An Early Australian Case Study of Curriculum Renewal' International Conference on the Future of Legal Education (Georgia State University College of Law, Atlanta: 2008

Lord Chancellor's Advisory Committee on Legal Education and Conduct (1996). First Report on Legal Education and Training. [ACLEC Report] London.

McInnis, C. 'Researching the First Year Experience: Where to from here?' (2001) Higher Education Research and Development, 20:2, 105-114.

McNamara, J. and Cockburn, T. L. and Shirley, M. J. Creating and enabling opportunities for increased student participation in experience based learning in professional practice. Experience Based Learning Association Inaugural Conference, 79 December 2009, University of Technology Sydney, Sydney.

McNamara, N. 'Authentic assessment in contract law: legal drafting,' (2017) The Law Teacher, 51:4, 486-498 p487

Molot, J. T. 'Purism and Pragmatism in the Legal Profession,' 31 Geo. J. Legal Ethics 1 (2018) p24

Mueller, J. The Authentic Assessment Toolbox: Enhancing Student Learning Through Online Faculty Development, Journal of Online Learning and Teaching http://jolt.merlot.org/vol1no1/mueller.htm

Quality Assurance Agency, Law Benchmark statements (July 2015) http://www.qaa.ac.uk/en/Publications/Documents/SBS-Law-15.pdf

Report of the Committee on Legal Education, CMND. No. 4595 (1971) (Ormrod)

Rigg, D. 'Embedding employability in assessment: searching for the balance between academic learning and skills development in law: a case study,' The Law Teacher, 47:3, 404-420

Royal Commission on Legal Services (1979). Final Report. [The Benson Report] Cmnd 7648, London, HMSO. 
Solicitors Regulation Authority Education and Training Committee Day One Outcomes April 2007 available from http://www.sra.org.uk/sra/news/day-one-outcomesrefined.page (accessed 9th July 2018)

Solicitors Regulation Authority Legal Practice Course Outcomes 2011available from https://www.sra.org.uk/students/lpc.page (accessed 6th July 2018)

Solicitors Regulation Authority Training Regulations 2014 - Qualification and Provider Regulations. Version 19 of the Handbook was published on 1 October 2017 available from https://www.sra.org.uk/solicitors/handbook/trainingregs2014/content.page (accessed 5th July 2018)

Solicitors Regulation Authority: Solicitors Qualifying Examination: Draft Assessment Specification October 2016

Stickley, A. Providing a law degree for the "real world": perspective of an Australian law school, (2011) The Law Teacher, 45:1, 63-86,

The Carnegie Foundation for the Advancement of Teaching 2007 available at http://archive.carnegiefoundation.org/pdfs/elibrary/elibrary_pdf_632.pdf (accessed 9th July 2018)

'The Ormrod Report.' (1972) 12(1) J Society of Public Teachers of Law issue 1 pages 39-55

Turner, T., Bone, A. and Ashton, J. 'Reasons why law students should have access to learning law through a skills-based approach,’ (2018) The Law Teacher, 52:1, 1-16 p3

Wallace, C. J. 'Using oral assessment in law; opportunities and challenges' (2010) The Law Teacher, 44:3, 365 - 377

Wallace, C. J. Using oral assessment in law; opportunities and challenges, (2010) The Law Teacher, 44:3, 365 - 377

Webb, J. Ching, J. Maharg, P. and Sherr, A. Setting Standards: The Future of Legal Services Education and Training Regulations in England and Wales (London, Legal Education and Training Review, 2013) (LETR Report) 
